\title{
Assessment of Regular Physical Activity in the Care of Hypertensive Patients at the Cardiology Institute of Abidjan and at the National Police Hospital (Ivory Coast)
}

\author{
Koffi Djinguin 1,2,3*, Gnaba Ambroise4, Ekou Arnaud1,2, Koffi Florent',2, Niamke Thierry1,2, \\ Tanoh Micesse ${ }^{1,2}$, Kramoh Euloge ${ }^{1,2}$ \\ ${ }^{1}$ Universite Felix Houphouet Boigny d'Abidjan, Cocody, Côte d'Ivoire \\ ${ }^{2}$ Institut de Cardiologie d'Abidjan, Abidjan, Yopougon, Treichville, Côte d'Ivoire \\ ${ }^{3}$ Hôpital de la Police Nationale, Yopougon, Côte d'Ivoire \\ ${ }^{4}$ Universite Alassane Ouattara, Bouaké, Côte d'Ivoire \\ Email: *koffidjinguin@yahoo.fr
}

How to cite this paper: Djinguin, K., Ambroise, G., Arnaud, E., Florent, K., Thierry, N., Micesse, T. and Euloge, K. (2020) Assessment of Regular Physical Activity in the Care of Hypertensive Patients at the Cardiology Institute of Abidjan and at the National Police Hospital (Ivory Coast). World Journal of Cardiovascular Diseases, 10, 648-657. https://doi.org/10.4236/wjcd.2020.109062

Received: April 17, 2020

Accepted: September 18, 2020

Published: September 21, 2020

Copyright $\odot 2020$ by author(s) and Scientific Research Publishing Inc. This work is licensed under the Creative Commons Attribution International License (CC BY 4.0).

http://creativecommons.org/licenses/by/4.0/

\begin{abstract}
Aim: Physical activity and other lifestyle changes are an important part of the guidelines for anti-hypertensive therapy. The effect of physical activity on hypertension and heart disease has been well described. No study in our context has been done on this issue. The aim of this study was to evaluate regular physical activity in the management of hypertensive patients at the Cardiology Institute of Abidjan and the National Police Hospital. Material and methods: This was a prospective and descriptive study held in the External Consultations and Rehabilitation Departments of the aforementioned structures. It started on July 20, 2017 and ended on September 7, 2017. The data were analyzed on SPSS version 22. A p-value of less than 0.05 was considered to be statistically significant. Results: Out of the 190 hypertensive patients recruited and educated, only 70 actually participated in the physical activities that took place in the Rehabilitation Department of Heart Institute. The mean age of the patients was 52 years \pm 15 years. The most affected age group was between 40 and 49 years of age (47.40\%). There was a male predominance with a sex ratio of $1.11 .63 .16 \%$ of the patients had a superior. The follow-up time for Hypertension was more than one year in $73.68 \%$ of the cases. Our study highlighted the knowledge of the virtues of regular physical activity on the body in $94.74 \%$ of cases. Physical activity was prescribed in $94.74 \%$ of cases. It was practiced in $63.16 \%$ of cases. The mains reasons given for those who did not practice physical activity were "lack of willpower" (90\%) and physical activity considered "too tiring" (70\%). Physically active patients had
\end{abstract}


a significant decrease of $17.98 \mathrm{mmHg}$ in systolic blood pressure $(\mathrm{p}<0.001)$ and $11.54 \mathrm{mmHg}$ in diastolic blood pressure $(\mathrm{p}<0.001)$. Conclusion: The practice of physical activity in the control of hypertension remains insufficient at the Abidjan Heart Institute. Despite this insufficiency, physical exercise seems to have a positive effect on blood pressure control associated with antihypertensive pharmacological treatment.

\section{Keywords}

Regular Physical Activity, Hypertension, Abidjan

\section{Introduction}

Globally, hypertension is the main risk factor for morbidity and mortality [1]. In Ivory Coast, hypertension data indicated a prevalence rate of $25 \%$ in 2005 according to the STEPS survey [2]. Lifestyle factors, including physical inactivity, are important modifiable risk factors in the development of hypertension. In addition to standard anti-hypertensive therapy, the benefits of physical activity on hypertension and cardiovascular disease have been well demonstrated [3] [4] [5] [6]. As a result, physical activity and other lifestyle changes are an important part of the guidelines for anti-hypertensive therapy [7] [8]. While the effect of physical activity on hypertension and heart disease has been well described, no study in our context has been done on this issue. The aim of this study was to evaluate regular physical activity in the management of hypertensive patients at the HIA and the NPH in Ivory Coast.

\section{Material and Methods}

It was a prospective and descriptive study that took place in the Departments of External Consultations and Rehabilitation of the HIA and the NPH. It started on July 20, 2017 and ended on September 7, 2017 for a total duration of 48 days. It took place in two phases. The first phase consisted in recruiting our study population, which consisted of hypertensive patients who attended and agreed to participate in the consultation services of these centers. In the second phase, the patients recruited are referred to the HIA Rehabilitation Service to benefit from an hour-long walking session, three times a week. They were supervised by two supervisors. Of the 190 hypertensive patients recruited and educated, only 70 actually participated in physical activities. To achieve our goal, we have developed a questionnaire.

The questionnaire included socio-professional characteristics of the patients, knowledge of hypertension and PRA. This questionnaire also included average mean blood pressure levels before and after physical activity during the study period. These parameters were taken by the supervisors through two approved electronic blood pressure monitors, OMRON M3 brand.

The data collected on the survey sheet were entered on the EPIDATA software 
and were analyzed on SPSS version 22. The quantitative variables were expressed as means \pm standard deviation and the statistical tests were carried using the $\mathrm{T}$ Student test. The qualitative variables were expressed as proportions and the statistics were obtained using the chi-square test. A p-value less than 0.05 was considered to be statistically significant.

\section{Results}

\section{On the socio-professional characteristics of the patients}

In our study, the mean age of the patients was 52 years \pm 15 years. The most affected age group was between 40 and 49 years (47.40\%). We noted a male predominance with a sex ratio of 1.11 . In our study, $42.11 \%$ of the respondents were public servants (Table 1). According to the level of education, $63.16 \%$ of the patients had a superior (Table 2). The follow-up time for hypertension was more than one year in $73.68 \%$ of cases (Table 3 ).

Table 1. Distribution of patients by sector of activity.

\begin{tabular}{ccc}
\hline Sector of activity & Numbers & $\%$ \\
\hline Employ of the private & 30 & 15.79 \\
Official profession & $\mathbf{8 0}$ & $\mathbf{4 2 . 1 1}$ \\
Liberal profession & 30 & 15.79 \\
Retirement & 30 & 15.79 \\
Unemployed & 20 & 10.53 \\
Total & 190 & 100 \\
\hline
\end{tabular}

Table 2. Distribution by level of study of patients.

\begin{tabular}{ccc}
\hline Study Level & Numbers & $\%$ \\
\hline Out of school & 10 & 5.26 \\
Primary & 30 & 15.79 \\
Secondary & 30 & 15.79 \\
High school & 120 & 63.16 \\
Total & 190 & 100 \\
\hline
\end{tabular}

Table 3. Distribution according to the follow-up period of Hypertension.

\begin{tabular}{ccc}
\hline & Numbers & $\%$ \\
\hline Less than 1 year & 20 & 10.53 \\
1 to 2 years & 40 & 21.05 \\
2 to 4 years & 60 & 31.58 \\
5 to 10 years & 40 & 21.05 \\
Unspecified & 30 & 15.79 \\
Total & 190 & 100 \\
\hline
\end{tabular}




\section{Knowledge and practice of patient RPA}

Our study highlighted the knowledge of the virtues of regular physical activity on the body in $94.74 \%$ of cases (Table 4). In our series, $94.74 \%$ of patients received a prescription for physical activity (Table 5). It was performed in $36.84 \%$ of cases (Table 6). The reasons cited for those who did not participate in physical activity were "lack of willpower" (90\%), physical activity found "too tiring" (70\%) and "lack of time" (60\%).

\section{Physical activity and blood pressure}

There was no difference between patients who received the prescription of PRA and the opposite group before the practice of PRA in terms of blood pressure levels (Table 7). In patients who participated in physical activity, there was a significant decrease of $17.98 \mathrm{mmHg}$ in systolic blood pressure $(\mathrm{p}<0.001)$. Diastolic blood pressure decreased significantly by $11.54 \mathrm{mmHg}(\mathrm{p}<0.001)$ (Table 8).

Table 4. Distribution according to the knowledge of the virtues of physical activity on the body.

\begin{tabular}{ccc}
\hline Knowledge of the virtues of physical activity & Numbers & $\%$ \\
\hline Yes & 180 & 94.74 \\
No & 10 & 5.26 \\
Total & 190 & 100 \\
\hline
\end{tabular}

Table 5. Distribution of physical activity prescribed to patients by health staff.

\begin{tabular}{ccc}
\hline Prescribed physical activity by the doctor & Numbers & $\%$ \\
\hline Yes & $\mathbf{1 8 0}$ & $\mathbf{9 4 . 7 4}$ \\
No & 10 & 5.26 \\
Total & 190 & 100 \\
\hline
\end{tabular}

Table 6. Distribution of surveyed patients engaged in regular physical activity.

\begin{tabular}{ccc}
\hline Regular physical activity & Number & $\%$ \\
\hline Yes & 70 & 36.84 \\
No & 120 & 63.16 \\
Total & 190 & 100 \\
\hline
\end{tabular}

Table 7. Mean patient blood pressure levels prior to RPA.

\begin{tabular}{lccc}
\hline & $\begin{array}{c}\text { Patients with PRA prescription } \\
\mathrm{n}=180\end{array}$ & $\begin{array}{c}\text { Patients without PRA prescription } \\
\mathrm{n}=10\end{array}$ & p-value \\
\hline $\mathrm{SBP}(\mathrm{mmHg})$ & $145.30 \pm 10$ & $142.82 \pm 11$ & 0.3594 \\
$\mathrm{DBP}(\mathrm{mmHg})$ & $92.15 \pm 8$ & $93.30 \pm 8$ & 0.7009 \\
\hline
\end{tabular}

Legend: SBP (Systolic blood pressure); DBP (Diastolic blood pressure). 
Table 8. Impact of PRA practice on pressure variation in patients who received PRA prescription after six months.

\begin{tabular}{lcccc}
\hline & \multicolumn{3}{c}{ PATIENTS WITH PRA PRESCRIPTION } \\
& $\mathrm{n}=180$ & \\
\cline { 2 - 4 } & $\begin{array}{c}\text { Patients RPA practice } \\
\mathrm{n}=70\end{array}$ & $\begin{array}{c}\text { Sedentary patients } \\
\mathrm{n}=110\end{array}$ & $\begin{array}{c}\text { Variation } \\
\text { of BP }\end{array}$ & \\
\hline $\mathrm{SBP}(\mathrm{mmHg})$ & $120.30 \pm 10$ & $138.28 \pm 11$ & -17.98 & $<0.001$ \\
$\mathrm{DBP}(\mathrm{mmHg})$ & $80.26 \pm 7$ & $91.80 \pm 8$ & -11.54 & $<0.001$ \\
\hline
\end{tabular}

Legend: SBP (Systolic blood pressure); DBP (Diastolic blood pressure); BP (blood pressure).

\section{Discussion}

\section{Limits of the Study}

They were essentially, the failure to assess patients with disabilities due to the painful standing position and the non-compliance of some patients. However, our study remains original because it is comparative. It assesses the prescribing of physical activity in the management of arterial hypertension. It highlights the contribution of the physical activity in the control of the arterial pressure of hypertensive.

In terms of socio-demographic characteristics, the age group most concerned was 40 to 50 years old. These observations show that hypertension increasingly affects young people. However, the exact prevalence of hypertension in young people according to the literature is relatively difficult to assess, due to the very different data available according to age groups, ethnicity, selection criteria, methodology applied for blood pressure measurements, oscillometric techniques, the number of blood pressure measurements available and the number of hospital visits for populations. In any event, it has been estimated that almost one in five young adults have high blood pressure [9].

Male predominance is observed until the sixth decade of life [10].

Basic scientific research has identified several possible mechanisms responsible for the observed differences between men and women in hypertension. This is the divergent role of the immune system in hypertensive men and women [11]. Our patient's level of study was high (63.16\% higher level). This is an important factor in the integration of right habits to adopt for the proper monitoring and implementation of health staff recommendations.

Our study found that very few (36.84\%) engaged in physical activity. Paradoxically, $94.74 \%$ of patients had a good knowledge of the virtues of practicing RPA on the body. Our data can be superimposed on those of Mona in Kuwait [12].

In this study, approximately $94.74 \%$ of doctors advised their patients to practice physical activity and only $63.16 \%$ practiced it. The reasons for the deficit in the practice of RPA in our study were: lack of willpower, physical activity found tiring and lack of time. Our results can be superimposed on those of Mona who found a main obstacles to the practice of physical activity reported, "lack of 
time", "lack of desire" and "lack of conviction of the benefits" (12\%) [12].

In our study, in patients who participated in physical activity, there was a significant decrease of $17.98 \mathrm{mmHg}$ in systolic blood pressure $(\mathrm{p}<0.001)$. Diastolic blood pressure decreased significantly by $11.54 \mathrm{mmHg}(\mathrm{p}<0.001)$.

These results justify the recommendations of the American working group on prevention services [13]. This group recommends that health care providers advise health professionals to promote regular physical activity [13]. And in a cluster randomized controlled trial in eastern New Zealand, counselling patients in general practice increased physical activity and quality of life, and that the procedure could reduce blood pressure by 1 to $2 \mathrm{mmHg}$ on average over 12 months [14].

\section{Conclusion}

The practice of physical activity in the control of hypertension remains insufficient in Ivory Coast. Despite this insufficiency, physical exercise appears to have a positive effect on the control of blood pressure associated with antihypertensive treatment. The results of our study suggest that healthcare professionals should be in the habit of prescribing physical activity as resolutely as antihypertensive drugs and hygienic-dietary measures. This prescription must include frequency, duration, intensity and evaluation. It is important that patients be monitored regularly to confirm adherence to the management plan and that the blood pressure objectives are being met.

\section{Conflicts of Interest}

The authors declare that they have no competing interest.

\section{References}

[1] Campbell, N.R.C., Lackland, D.T. and Niebylski, M.L. (2014) The World Hypertension League and International Society of Hypertension Executive Committees. High Blood Pressure: Why Prevention and Control Are Urgent and Important-A 2014 Fact Sheet From the World Hypertension League and the International Society of Hypertension. The Journal of Clinical Hypertension, 16, 551-553. https://doi.org/10.1111/jch.12372

[2] OMS. (2005) Enquête sur les facteurs de risque des maladies non transmissibles. Région sanitaire des Lagunes. Côte d'Ivoire. Direction de coordination du programme STEPS/MNT.

[3] Diaz, K.M. and Shimbo, D. (2013) Physical Activity and the Prevention of Hypertension. Current Hypertension Reports, 15, 659-668.

https://doi.org/10.1007/s11906-013-0386-8

[4] Cornelissen, V.A. and Fagard, R.H. (2005) Effects of Endurance Training on Blood Pressure, Blood Pressure-Regulating Mechanisms, and Cardiovascular Risk Factors. Hypertension, 46, 667-675. https://doi.org/10.1161/01.HYP.0000184225.05629.51

[5] Leitzmann, M.F., Park, Y., Blair, A., et al. (2007) Physical Activity Recommendations and Decreased Risk of Mortality. Archives of Internal Medicine, 167, 2453-2460. 
https://doi.org/10.1001/archinte.167.22.2453

[6] Rossi, A., Dikareva, A., Bacon, S.L. and Daskalopoulou, S.S. (2012) The Impact of Physical Activity on Mortality in Patients with High Blood Pressure: A Systematic Review. Journal of Hypertension, 30, 1277-1288. https://doi.org/10.1097/HJH.0b013e3283544669

[7] Members, A.F., Mancia, G., Fagard, R., Narkiewicz, K., Redon, J., Zanchetti, A., et al. (2013) 2013 ESH/ESC Guidelines for the Management of Arterial Hypertension. European Heart Journal, 34, 2159-2219. https://doi.org/10.1093/eurheartj/eht151

[8] Mendis, S. (2014) World Health Organization. Global Status Report on Noncommunicable Diseases 2014. https://doi.org/10.1161/STROKEAHA.115.008097

[9] Perk, J., De Backer, G., Gohlke, H., Graham, I., Reiner, Z., Verschuren, M., et al. (2012) European Guidelines on Cardiovascular Disease Prevention in Clinical Practice (Version 2012). The Fifth Joint Task Force of the European Society of Cardiology and Other Societies on Cardiovascular Disease Prevention in Clinical Practice (Constituted by Representatives of Nine Societies and by Invited Experts). European Heart Journal, 33, 1635-1701. https://doi.org/10.1093/eurheartj/ehs092

[10] Yoon, S.S., Gu, Q., Nwankwo, T., Wright, J.D., Hong, Y. and Burt, V. (2015) Trends in Blood Pressure among Adults with Hypertension: United States, 2003 to 2012. Hypertension, 65, 54-61. https://doi.org/10.1161/HYPERTENSIONAHA.114.04012

[11] Ellen Gillis, E. And Jennifer Sullivan, C. (2016) Sex Differences in Hypertension: Recent Advances. Hypertension, 68, 1322-1327. https://doi.org/10.1161/HYPERTENSIONAHA.116.06602

[12] Alsairafi, M. and Alshamali, K. (2010) Effect of Physical Activity on Controlling Blood Pressure among Hypertensive Patients from Mishref Area of Kuwait. European Journal of General Medicine, 7, 377-384. https://doi.org/10.29333/ejgm/82889

[13] U.S. Preventive Services Task Force (2002) Behavioral Counseling in Primary Care to Promote Physical Activity. Agency for Healthcare Research and Quality, Rockville, MD.

[14] Elley, C.R., Kerse, N., Arroll, B. and Robinson, E. (2003) Effectiveness of Counseling Patients on Physical Activity in General Practice: Cluster Randomized Controlled Trial. BMJ, 326, 793-798. https://doi.org/10.1136/bmj.326.7393.793 


\section{Questionnaire}

Assessment of regular physical activity in the care of hypertensive patients at the cardiology institute of Abidjan and at the national police hospital (Ivory Coast)

I. Epidemiologic data

1) Sexe

$\mathrm{M} \square \mathrm{F} \square$

2) What age group are you in (years)?

$20-30 \square 30-40 \square 40-50$ ans $\square 50-60 \square 60-70$ ans $\square+$ De 70 ans $\square$

3) What is your activity sector?

Private employee $\square$ civil servant $\square$ liberal profession $\square$

Retired $\square$ unemployed $\square$ other $\square$ specified...

4) What is your level of education?

Primary level $\square$ secondary level $\square$ higher level $\square$ no schooling $\square$ other $\square$ specify...

5) Do you currently exercise a professional activity?

Yes $\square$ no $\square$

If so, what means do you use to get to your workplace?

On foot $\square$ personal car $\square$ public transport $\square$ bicycle $\square$ motorcycle $\square$ If not, why?

6) What is the distance between your place of residence and your place of work?

From $1 \mathrm{~km} \square$ Between 1 and $2 \mathrm{~km} \square$ Between 3 and $5 \mathrm{~km} \square 5$ to $10 \mathrm{~km} \square 15$ to $20 \mathrm{~km} \square+$ From $20 \mathrm{~km} \square$

7) Since when were you tested for hypertension?

From 1 year $\square 1$ to 2 years $\square 2$ to 4 years $\square 5$ to 10 years $\square+$ From 10 years $\square$

II. Question relating to the knowledge and attitudes of patients

8) What is hypertension?

9) What do you think hypertension treatment is based on?

Antihypertensive drugs $\square$

The others (hygieno-dietetic measures the practice of regular physical activity)

10) What do you think are the causes of hypertension

Sedentary lifestyle $\square$ Obesity $\square$ Alcohol $\square$ Tobacco $\square$ Heredity $\square$ Curse $\square$ No cause $\square$ specify $\square$.

11) Do you know the virtues of activity on the body?

Yes $\square$ no $\square$ quote them...

12) What is physical activity?

Do housework, garden, tinker regularly $\square$

Shopping at the supermarket once a week $\square$

Walk unsuccessfully a distance of $3 \mathrm{~km}$ for at least 30 minutes $\square$

Run a distance of more than $3 \mathrm{~km} \square$ Jogging $\square$ Walk a distance of $1 \mathrm{~km} \square$

Cycling $\square$ Lift heavy objects $\square$ Play video games and chat with friends on so- 
cial networks $\square$ Visiting loved ones every weekend $\square$

13) Do you participate in regular physical activity?

Yes $\square$ no $\square$

If yes which swimming $\square$ jogging $\square$ walking $\square$ stretching $\square$ other $\square$ specify...

If not, why Too tiring $\square$ No will $\square$ My doctor did not tell me to play sports $\square$

No place to practice physical activity $\square$ I don't like sport $\square$ No time $\square$

14) When do we say physical activity is regular?

1 time/week $\square 1$ time/month $\square 2$ times/week $\square 4$ times/week $\square$

Every day of the week $\square$

15) When do we say that an RPA is good for the body?

10 minutes moderate to intense $\square 10$ minutes lightly $\square$

3 times 10 minutes moderately $\square 45$ minutes lightly $\square$

More than 60 minutes moderately $\square$

16) How do you get to your consultation appointments?

On foot $\square$ By personal car $\square$ Bike $\square$ Motorcycle $\square$ Public transport $\square$

17) In your opinion, where can we practice a physical activity?

In an area suitable only for sport $\square$ In a gym $\square$ In a corner of his house $\square$

Going to work $\square$ Everywhere you can $\square$

18) Has your doctor prescribed physical activity for you?

Yes $\square$ no $\square$

If so, what activity?

Jogging $\square$ Walking $\square$ Fitness $\square$ Swimming $\square$ Others $\square$ specify

How frequently?

Once/month $\square$ Once/month $\square 3$ times/week $\square 45$ times/week $\square$ Every day of the week $\square$

And for how long?

10 minutes $\square 3$ times 10 minutes $\square 30$ minutes $\square$

45 minutes $\square 60$ minutes $\square 60$ minutes $\square$ According to my abilities $\square$

19) Did your blood pressure return to normal with the prescribed treatment?

Yes $\square$ no $\square$

If so, what do you think this is due to?

a) The correct medication $\square$

b) The regular practice of a physical activity $\square$

c) Recommendations on good dietary hygiene habits $\square$

If not, why do you think?

a) Incorrectly taking medication $\square$

b) Correct taking of medication but not practicing physical activity $\square$

c) Incorrect intake of medication, non-practice of physical activity and non-follow-up of hygiene and dietetic measures $\square$

d) I have no idea $\square$

20) How do you know your blood pressure is high?

During checks $\square$ When I have a headache and dizziness $\square$

21) Do you have a notebook where you mark your blood pressure? 
Yes $\square$ no $\square$

22) What were your blood pressure figures when you last took it?

a) $\geq 140 / 90 \mathrm{mmHg} \square$ b) $135 / 85 \mathrm{mmHg} \square$

c) $120 / 80 \mathrm{mmHg} \square$ d) $110 / 60 \mathrm{mmHg} \square$

23) What does your doctor insist on during your appointments at the office?

Taking medication correctly $\square$

The respect of hygieno-dietetic measures $\square$

Regular practice of regular associated physical activity $\square$

24) What do you think helps you the most in treating your hypertension?

Taking medication correctly $\square$

The respect of hygieno-dietetic measures $\square$

Regular physical activity $\square$

25) How do you sum up your days?

Go to work $\square$ Watch television afternoon and evening respect $\square$

Go to bed after lunch when you are home on rest days $\square$ Go straight to bed after the evening meal $\square$ Shopping at home $\square$ Go to visit relatives $\square$

Go out with friends to chat $\square$ Coming home after hard work $\square$

Others $\square$ specify

26) What does it take for you to engage in regular physical activity?...

III. Impact regular physical activities and arterial pressure

- Including: SBP ... DBP ...

- Six months after regular physical activities: Including: SBP ... DBP ...

\section{List of Abbreviations}

STEPS survey: recommended by the WHO for the study of noncommunicable diseases in 2005 in Ivory Coast

$>$ HIA: Heart Institute of Abidjan

NPH: National Police Hospital

PRA: Physical Regular Activity 